\title{
FALEC wt Allele
}

National Cancer Institute

\section{Source}

National Cancer Institute. FALEC wt Allele. NCI Thesaurus. Code C119656.

Human FALEC wild-type allele is located in the vicinity of $1 \mathrm{q} 21.3$ and is approximately $2 \mathrm{~kb}$ in length. This allele, which encodes focally amplified long non-coding RNA in epithelial cancer, may play a role in tumorigenesis. 